\title{
Semi-arid savanna of the Potlake Nature Reserve and surrounding areas in Sekhukhuneland, South Africa
}

\author{
S.J. Siebert, M. Matthee and A.E. van Wyk
}

Siebert, S.J., M. Matthee and A.E. van Wyk. 2003. Semi-arid savanna of the Potlake Nature Reserve and surrounding areas in Sekhukhuneland, South Africa. Koedoe 46(1): 29-52. Pretoria. ISSN 0075-6458.

\begin{abstract}
A hierarchical classification, description, and ecological and floristic interpretations are presented on the vegetation types of the semi-arid northern savanna of the Sekhukhuneland Centre of Plant Endemism. Relevés were compiled in 47 stratified random plots. A TWINSPAN classification, refined by Braun-Blanquet procedures, revealed eight plant communities, classified as four associations, one of which is subdivided into five sub-associations. For each plant community, the floristic richness, endemism and conservation status was determined. Much of the plant community distribution can be ascribed to environmental factors and anthropogenic disturbance. An ordination (DECORANA), based on floristic data, showed environmental gradients that possibly exist between plant communities and associated habitats. The floristic information, proposed classification, general description and vegetation key, can be used for the identification and monitoring of protected areas, land-use planning, and further conservation research.
\end{abstract}

Key words: biodiversity, conservation, Limpopo, phytosociology, savanna, Sekhukhuneland, syntaxonomy, ultramafic.

S.J. Siebert, M. Matthee and A.E. van Wyk, Department of Botany, University of Pretoria, Pretoria, 0002 Republic of South Africa.

\section{Introduction}

Phytosociological studies have been conducted on savanna vegetation types of the Bushveld Complex in Limpopo Province (Bredenkamp \& Van Vuuren 1977; Breebaart \& Deutschlander 1997; Siebert et al. 2002b, 2002c). However, the vegetation of most areas still remains to be investigated and described, both on reconnaissance level and in more detail. Such an area is the semi-arid plains and hills of the Potlake Nature Reserve and surrounding Mecklenburg region, previously described as the Northern Dry Mixed Bushveld (Siebert et al. 2002a) of the Sekhukhuneland Centre of Plant Endemism (SCPE) (Siebert \& Van Wyk 2001; Van Wyk \& Smith 2001). The area is situated to the north of the Steelpoort Subcentre of the SCPE, which is floristically noteworthy in that many rare and endemic species with distributions correlated with the geological substrate occur here (Siebert et al. 2001, 2002d).
This paper forms part of a wider investigation into the vegetation of the SCPE (Siebert et al. 2002a). It is envisaged that the identification, classification and description of the various vegetation units of conservation areas will contribute to the knowledge of the plant diversity and biological intricacies of the region. Classification of the vegetation is essential for the formulation of a management policy and for proper land use planning. This paper shows which plant communities (and rare species) are presently conserved in Sekhukhuneland, and by comparison with data from Siebert et al. (2002b, 2002c, 2002d), it will identify ecosystems not presently conserved.

Therefore, the paper aims to provide ecological and floristic data of the region's semiarid bushveld and the associated habitats, by characterising and interpreting the vegetation units, as well as constructing a vegetation key to assist with the identification of plant communities in this homogeneous vegetation 
type. An assessment of the plant diversity, endemism/near-endemism and Red Data List taxa in the plant communities of the study area is supplied for future conservation planning initiatives in the region. The vegetation described here only includes those plant communities that are part of the Acacia tortilis-Eragrostis barbinodis Northern Dry Mixed Bushveld (Siebert et al. 2002a). A synthesis in the form of a phytosociological table is presented as a summary of the major vegetation types.

\section{Study area}

The study area is situated directly south of the Strydpoort Mountains in Limpopo Province between latitude $24^{\circ} 15^{\prime} 00^{\prime \prime}-$ $24^{\circ} 30^{\prime} 00^{\prime \prime} \mathrm{S}$ and longitude $29^{\circ} 30^{\prime} 00^{\prime \prime}-$ $30^{\circ} 10^{\prime} 00^{\prime \prime} \mathrm{E}$ (Fig. 1). This northern part of the SCPE is restricted to the eastern Bushveld Complex, situated on top of the Lower Zone of the Rustenburg Layered Suite (Visser et al. 1989). The Lower Zone stretches around the eastern side of the Leolo Mountains from Lebowakgomo eastward and then southward towards Steelpoort where it fades.

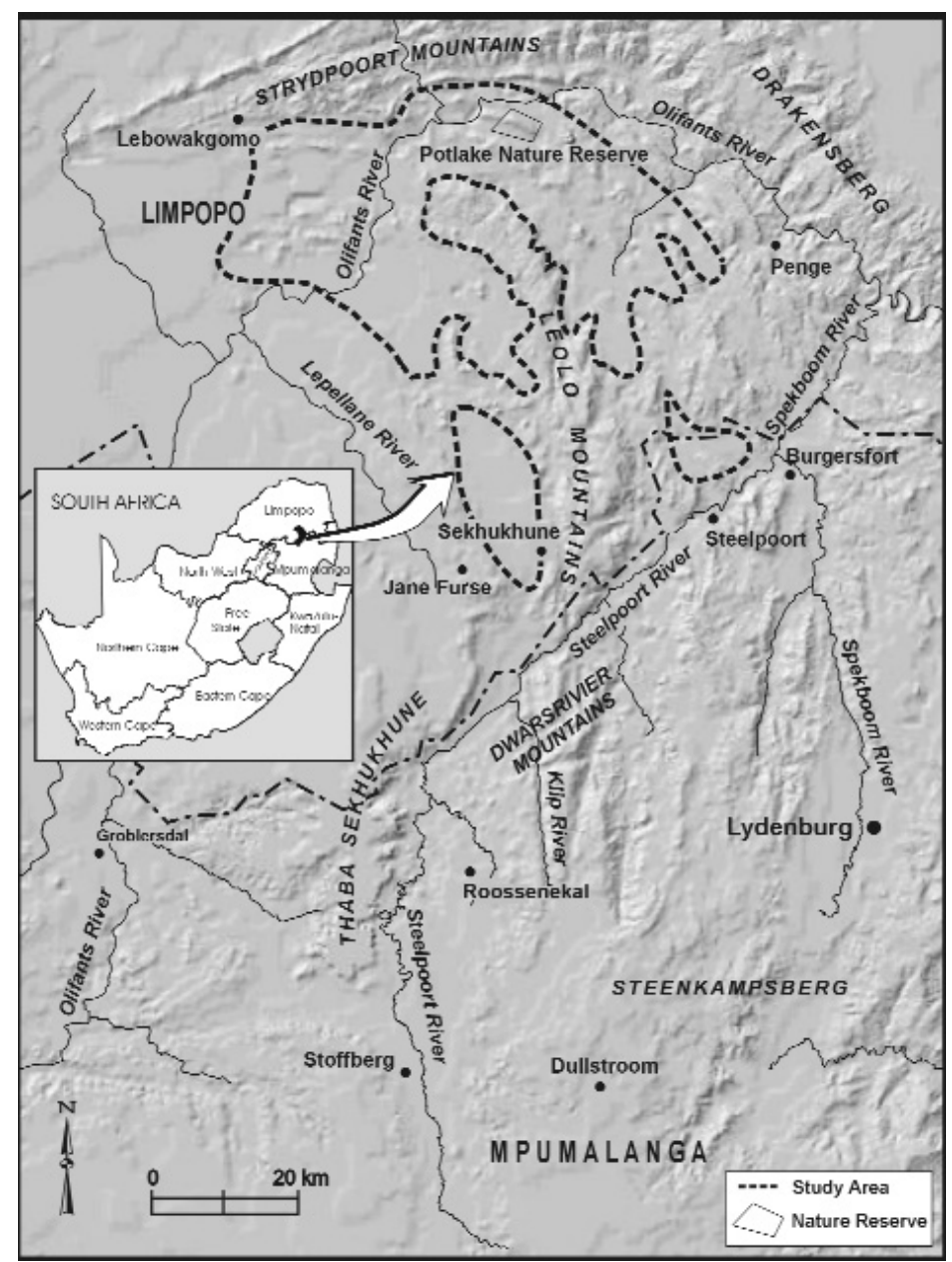

Fig. 1. Location of the semi-arid savanna of the Sekhukhuneland Centre in the Limpopo Province. 
The study area (Potlake Nature Reserve and surrounding areas) covers approximately $1250 \mathrm{~km}^{2}$ and comprises a moderately heterogeneous physiography (Land Type Survey Staff 1987), which is underlain by a heterogeneous geology of pyroxenite belts covered by surficial deposits of alluvium and scree (Visser et al. 1989). Other prominent rocks include Jagdlust harzburgite, Shelter norite and Karoo dolerite. Potlake Nature Reserve is small (approximately $30 \mathrm{~km}^{2}$ ) and conserves the vegetation of the largest serpentinised ultramafic outcrop in Sekhukhuneland.

Sekhukhuneland lies in the summer rainfall region, with the semi-arid northern parts receiving mean annual precipitation of 430 mm (South African Weather Bureau 1998). The rainfall pattern is strongly influenced by the area's topography (Siebert 1998), varying from $416 \mathrm{~mm}$ in the east to $499 \mathrm{~mm}$ in the west, and from $500 \mathrm{~mm}$ in the south to $456 \mathrm{~mm}$ in the north (Erasmus 1985). Daily temperatures range from a minimum of $8^{\circ} \mathrm{C}$ in winter to a maximum of $38^{\circ} \mathrm{C}$ in summer, with a mean annual temperature of $20{ }^{\circ} \mathrm{C}$ (South African Weather Bureau 1998). Temperatures vary at different localities within the study area, also correlating strongly with physiographic regions, being higher for lowlying valleys and lower for high-lying plateaus (Buckle 1996). Minimum temperatures of below freezing point are extremely rare, even at higher altitudes. The difference in altitude between the two most extreme locations is approximately 200 metres.

Bredenkamp \& Van Vuuren (1977) recognised various savanna vegetation types on the adjacent Pietersburg Plateau, which show a definite floristic affinity with the semi-arid savanna of the SCPE (Siebert et al. 2002a). In this semi-arid region of sequential bands of hills and plains, the predominant characteristic vegetation feature is low open savanna, which is mostly restricted to the ultramafic areas between the Leolo Mountains and the Strydpoort Mountains. Acocks (1988) mapped the vegetation of the study area as tropical bush and savanna veld types, namely Mixed Bushveld and Sourish Mixed
Bushveld. Acocks (1988) accurately distinguished the major vegetation type of the study area as Mixed Bushveld, which is an Acacia-dominated savanna of relatively drier plains (Siebert et al. 2002a). According to Acocks (1988) the vegetation of the mountain slopes of the Leolo Mountains' northern ranges is Sourish Mixed Bushveld, which links with the vegetation on the southern slopes of the Serala Subcentre and the western slopes of the Blyde River Subcentre (Matthews 1991). However, it is not a typical sour bushveld and needs to be studied further to determine its true identity, because the area under discussion is semi-arid (mean annual rainfall between 350 and $450 \mathrm{~mm}$ per annum). In the 1940s, Sekhukhuneland was already highlighted as an area that is rapidly becoming a semi-desert (Codd 1949).

\section{Methods}

Floristic and habitat data of the study area were obtained from 47 stratified random plots, sampled by Matthee in 1978, and verified by Siebert in 1998. Longitude and latitude readings were recorded for the 1978 sample units during the 1998 survey. Stratification was based on soil form, terrain type and aspect. To standardise the plot size for the Sekhukhuneland survey, plots in the savanna were fixed at $20 \mathrm{~m} \times 20 \mathrm{~m}$ (Siebert et al. 2002a). Within each sample plot, all species were recorded and a cover-abundance value assigned to each species according to the Braun-Blanquet scale (MuellerDombois \& Ellenberg 1974). Plant species names conform to those of Retief \& Herman (1997). Terminology to describe vegetation structure follows Edwards (1983). Environmental data recorded in each sample plot include terrain type, aspect, slope, geology, soil form and rockiness of soil surface. All relevé data are stored in the TURBOvEG database (Hennekens 1996a), and managed by the Department of Botany, University of Pretoria (Mucina et al. 2000).

A first approximation of a vegetation classification for the Sekhukhuneland region in general, based on the total floristic data set of 415 relevès (Siebert et al. 2002a), was obtained by the application of the TwoWay Indicator Species Analysis (TwINSPAN) (Hill 1979a). This first step identified several major vegetation types for the SCPE (Siebert et al. 2002a) and was used to subdivide the data set into five phytosociological tables. The table representing Northern 


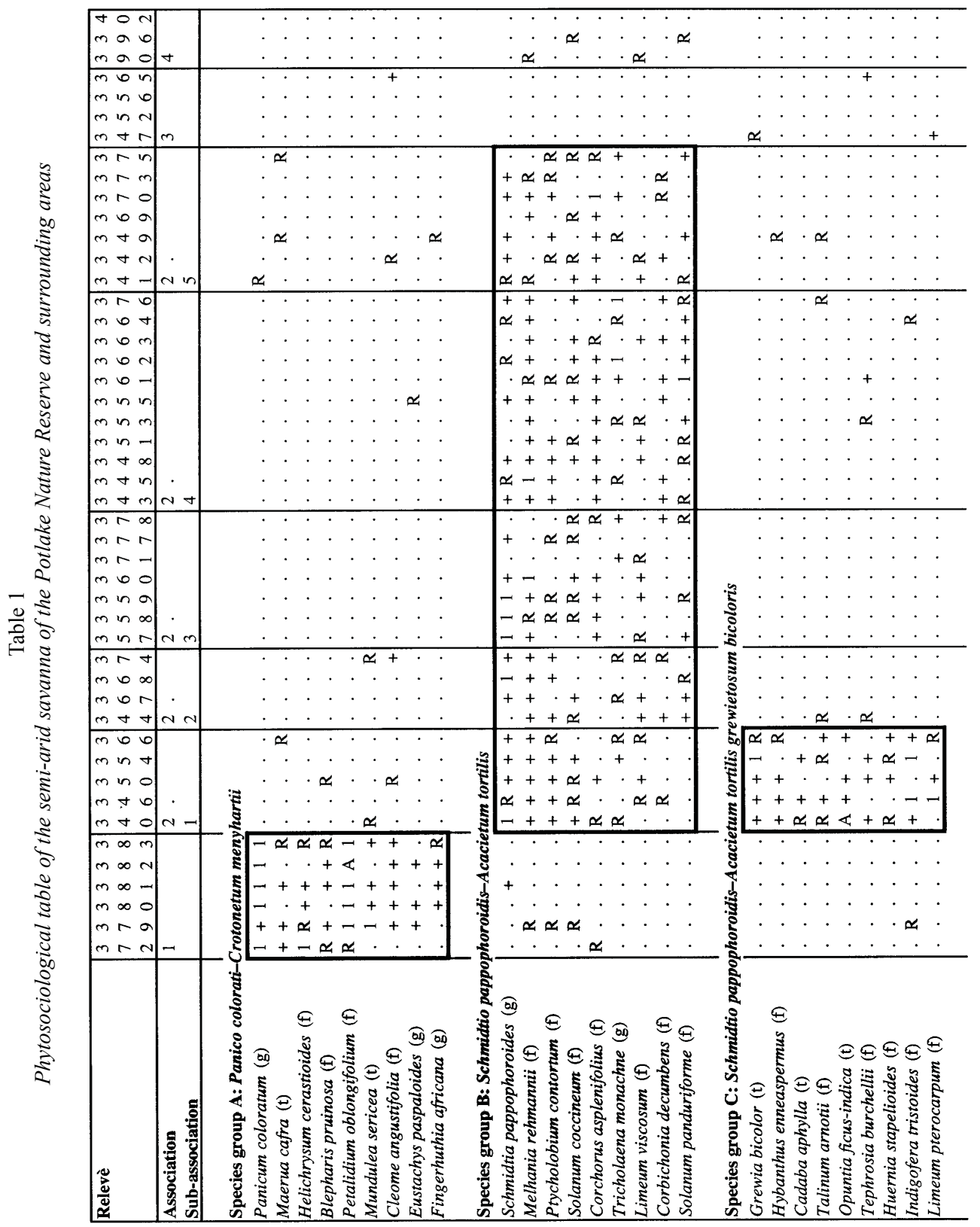




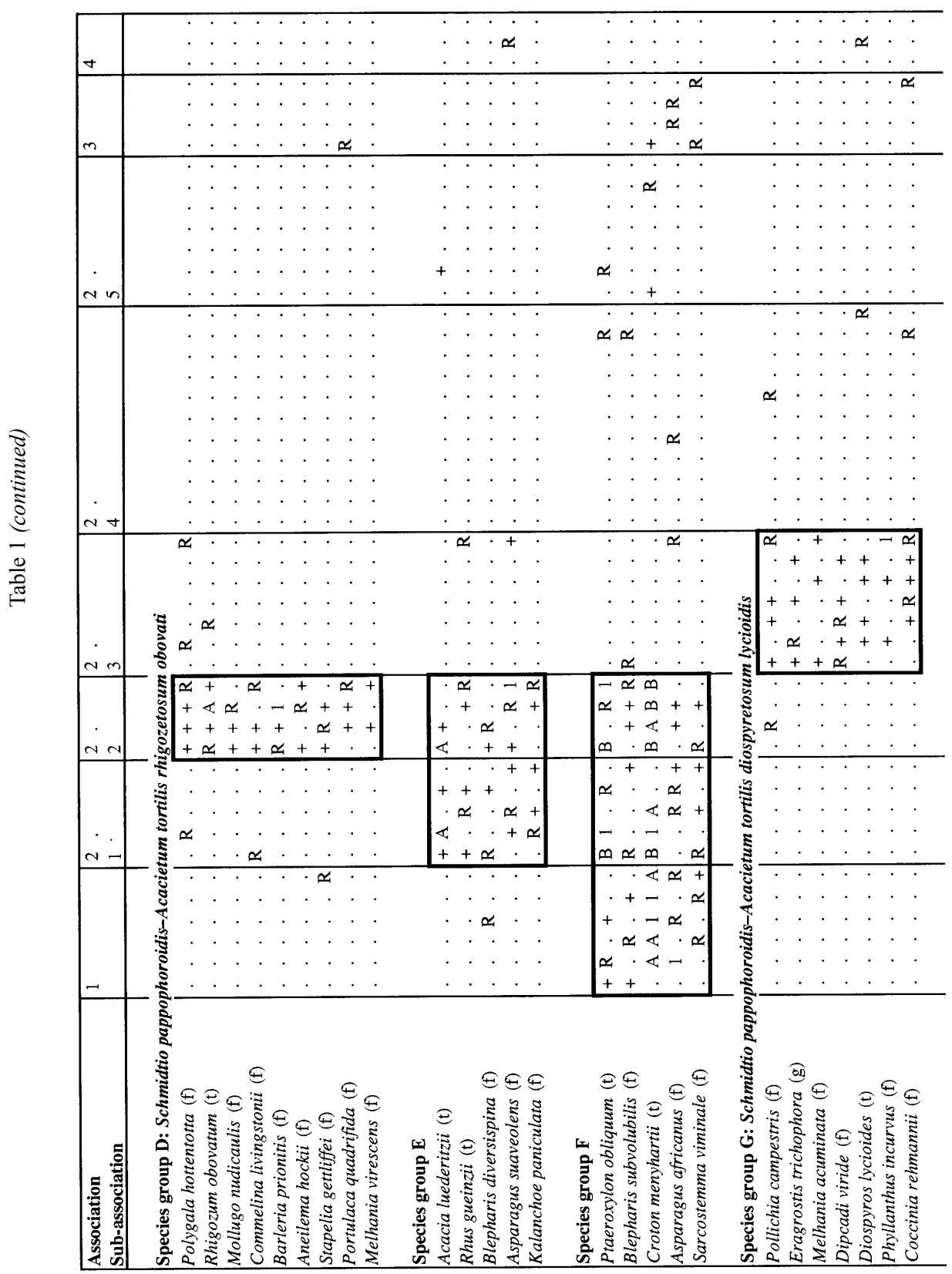




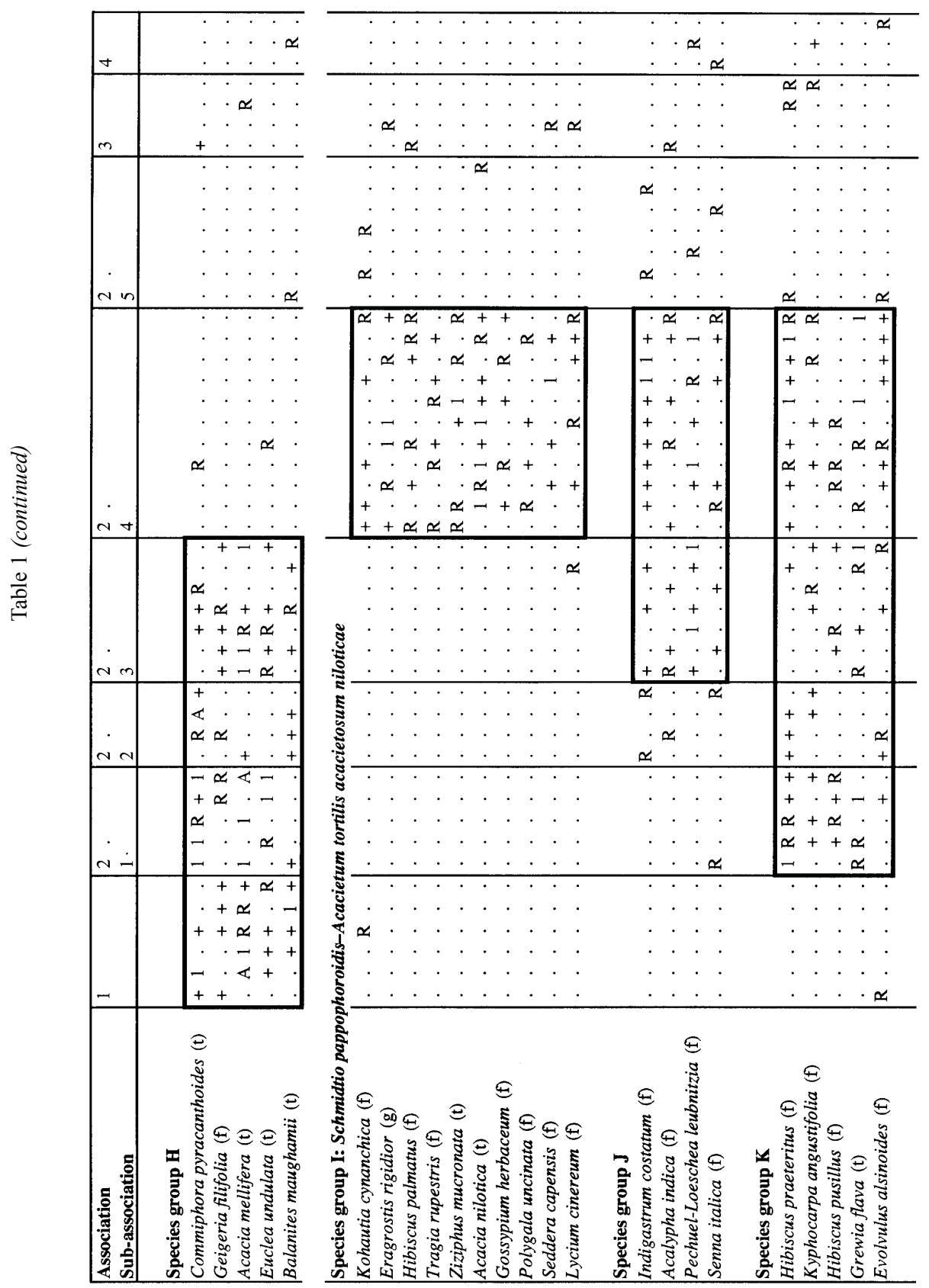




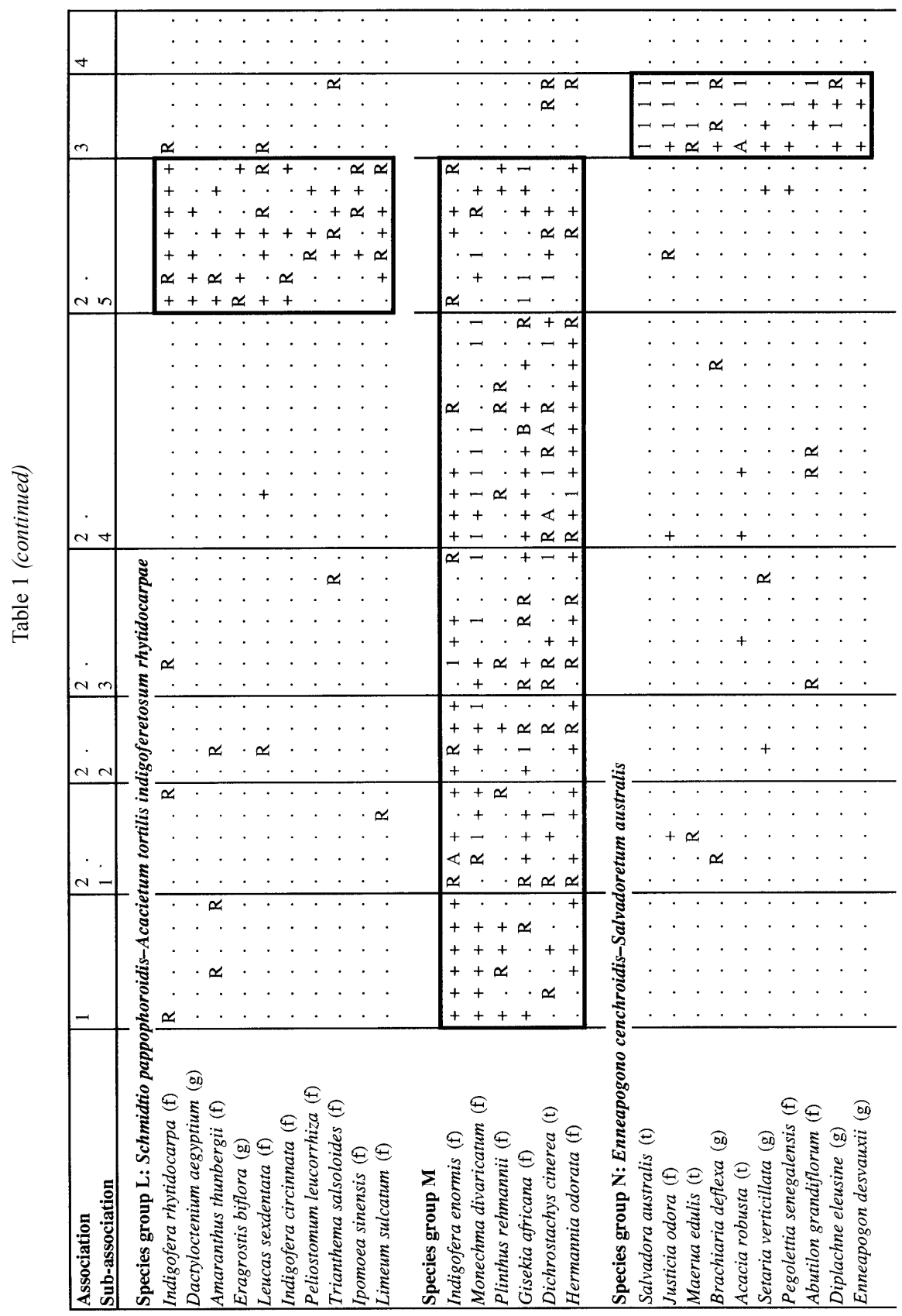




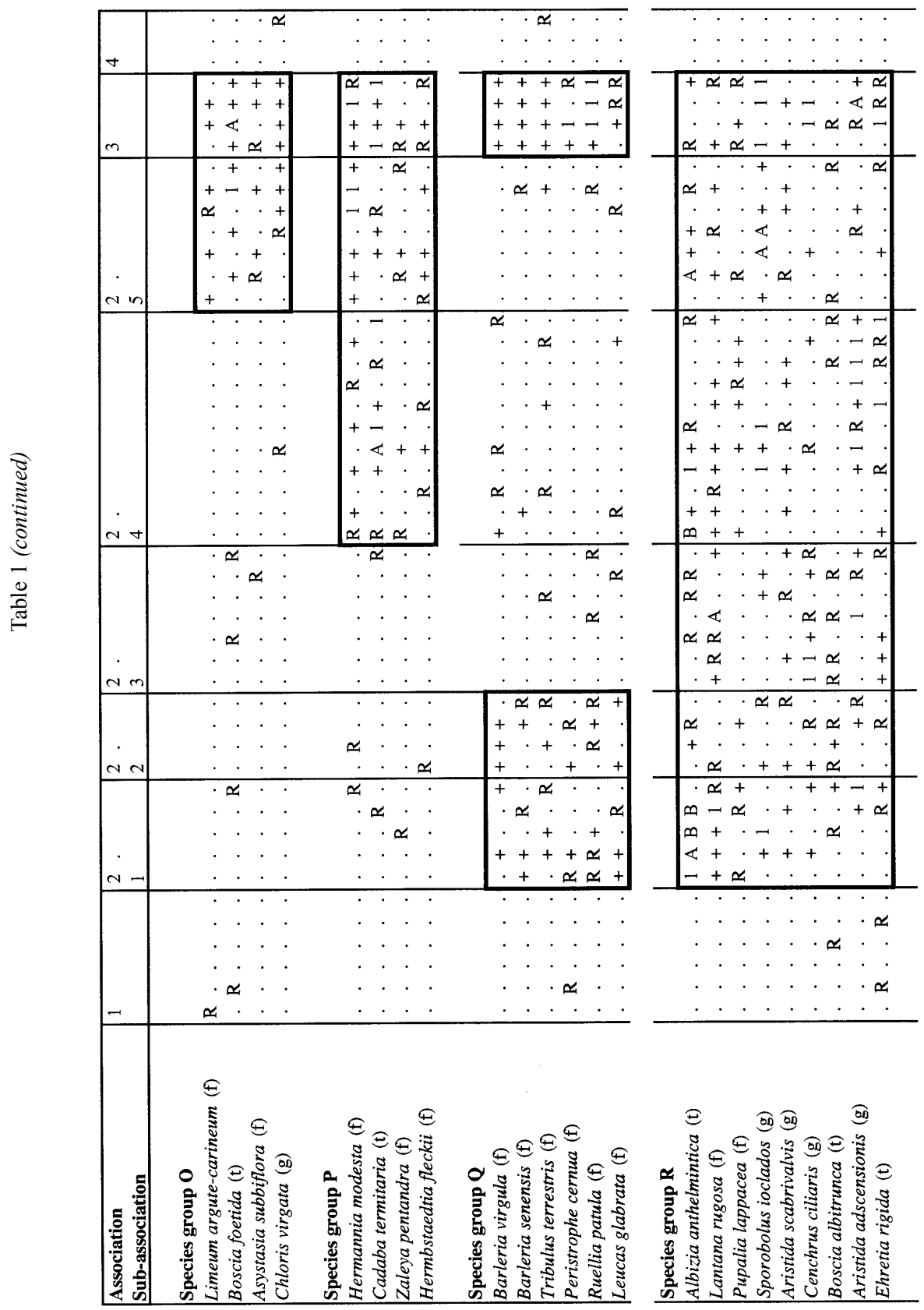




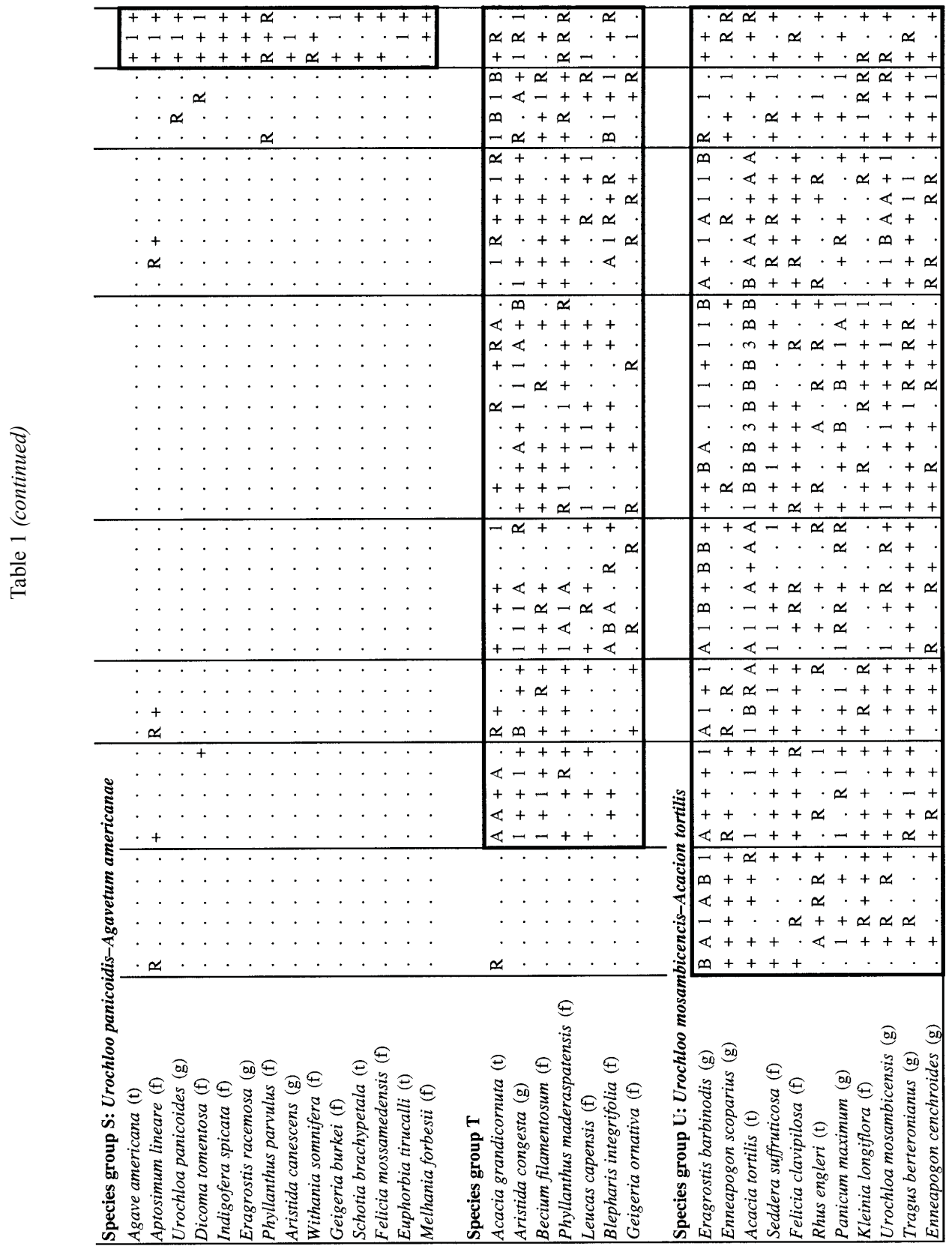


Dry Mixed Bushveld was again subjected to TWINSPAN. Braun-Blanquet procedures were used to further refine the resultant classification in the MEgATAB computer programme (Hennekens 1996b) (Table 1). All syntaxa were subsequently hierarchically classified and described according to the Code of Phytosociological Nomenclature (Weber et al. 2000).

The ordination algorithm Detrended Correspondence Analysis (DECORANA) (Hill 1979b) (Fig. 2) was applied to illustrate possible floristic relationships between communities and to confirm possible gradients between the vegetation and the physical environment.

In order to facilitate the identification of areas of high conservation potential, the alpha diversities of the different plant communities were calculated. The alpha diversity (plant species richness) is defined as the number of species per unit area within a homogeneous community or the total number of species per community (Whittaker 1977). A $400 \mathrm{~m}^{2}$ sample plot was taken as the unit area within a homogeneous community.

Distribution ranges of all the taxa were verified at the National Herbarium [PRE], Pretoria, to identify any taxa endemic to the region (Siebert et al. 2002d). All taxa were also checked against Red Data Lists of southern African plants (Hilton-Taylor 1996; Victor 2002) to determine their conservation status in South Africa.

Mean vegetation cover percentage (MCP) was determined for each species in every community. For the purpose of this study, MCP is the sum of a species' percentage cover in all the relevés of a community, divided by the total number of relevés for that community (species cover was determined using the following conversion from the Braun-Blanquet scale: $\mathrm{r}$ $=0.5 \% ;+=1 \% ; 1=3 \% ; \mathrm{A}=8 \%$; $\mathrm{B}=18 \% ; 3=$ $37 \%$ ). Species were grouped into their respective growth forms, namely trees, forbs or grasses, and the total vegetation cover percentage (TCP) was determined by adding the MCPs for each growth form in each community.

\section{Results and discussion}

\section{Classification}

Since the study area lies in the geological and climatically uniform dry and warm northern region of the Sekhukhuneland Centre (Siebert et al. 2002a), no major climatic variation plays a role in local differentiation of plant communities. Communities were not always distinctive in the field. This might be attributed to the homogeneity of the environmental factors, causing a complex transition pattern of habitats and associated vegetation. The hierarchical classification of the vegetation reinforces the relationship between habitat and plant communities (Fig. 2).

Major plant communities relate to soil properties, aspect and terrain type. A summary of selected community attributes is given in Table 2. Distribution of the 16 identified Sekhukhuneland endemic/near-endemic and rare/threatened species (Siebert et al. 2002d) among the various plant communities of this semi-arid savanna is listed in Table 3.

Analyses resulted in the identification of eight plant communities, classified as four associations, one of which is subdivided into five sub-associations (Table 1). Plant communities of the SCPE's semi-arid savanna (Acacia tortilis-Eragrostis barbinodis Northern Dry Mixed Bushveld) are classified as follows:

\section{Urochloo mosambicencis-Acacion tortilis}

\section{Panico colorati-Crotonetum menyhartii}

\section{Schmidtio pappophoroidis-Acacietum} tortilis

2.1 Schmidtio pappophoroidis-Acacietum tortilis grewietosum bicoloris

2.2 Schmidtio pappophoroidis-Acacietum tortilis rhigozetosum obovati

2.3 Schmidtio pappophoroidis-Acacietum tortilis diospyretosum lycioidis

2.4 Schmidtio pappophoroidis-Acacietum tortilis acacietosum niloticae

2.5 Schmidtio pappophoroidis-Acacietum tortilis indigoferetosum rhytidocarpae

\section{Enneapogono cenchroidis-Salvadoretum australis}

\section{Urochloo panicoidis-Agavetum ameri-} canae 


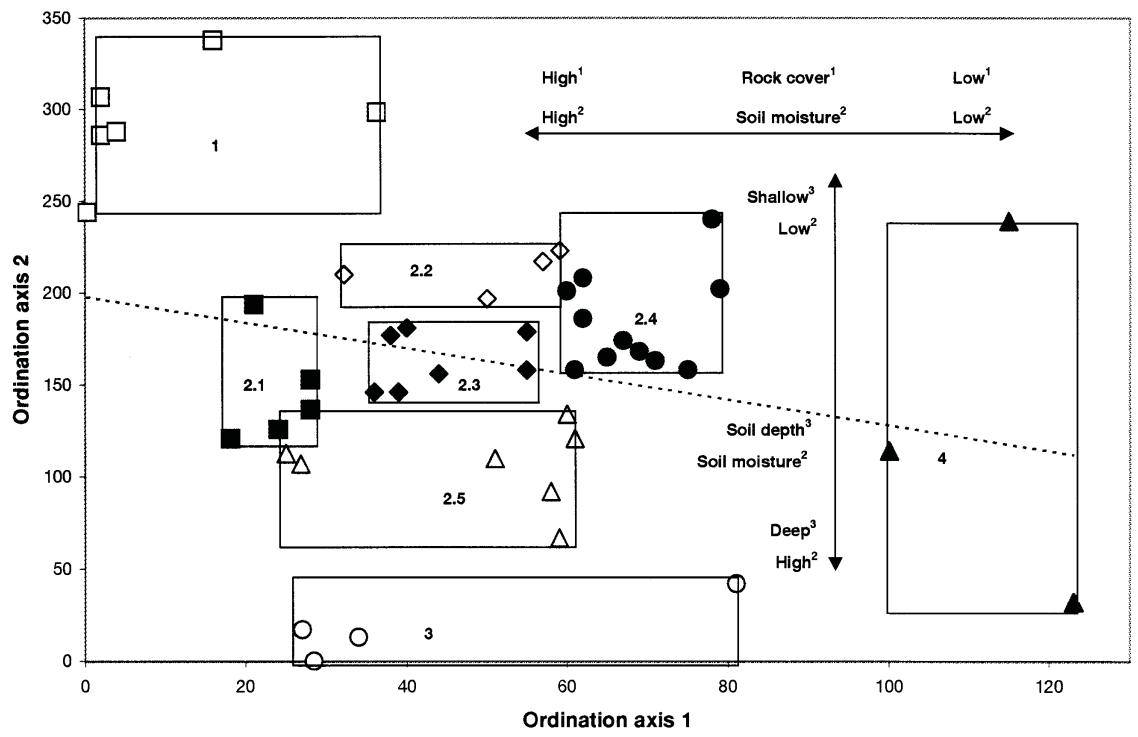

Fig. 2. Relative positions of all the relevés of the semi-arid savanna of the Sekhukhuneland Centre along the first and second axis of an ordination. Numbers correspond with the plant communities in Table 1.

Table 2

Environmental factors and selected attributes associated with the different plant communities of the Potlake Nature Reserve and surrounding areas

\begin{tabular}{|c|c|c|c|c|c|c|c|c|}
\hline \multirow[t]{2}{*}{ Factors/attributes } & \multicolumn{8}{|c|}{ Syntaxa } \\
\hline & 1 & 2.1 & 2.2 & 2.3 & 2.4 & 2.5 & 3 & 4 \\
\hline Number of relevés & 6 & 5 & 4 & 7 & 11 & 7 & 4 & 3 \\
\hline Total number of species & 59 & 110 & 92 & 87 & 110 & 109 & 98 & 55 \\
\hline Mean number of spp. per relevé & 25 & 50 & 46 & 34 & 38 & 39 & 48 & 24 \\
\hline Grass cover $(\%)$ & 14 & 9 & 12 & 17 & 19 & 18 & 15 & 6 \\
\hline Forb cover $(\%)$ & 8 & 16 & 15 & 19 & 16 & 12 & 20 & 8 \\
\hline Tree cover $(\%)$ & 10 & 28 & 27 & 2 & 8 & 3 & 10 & 3 \\
\hline Total vegetation cover (\%) & 32 & 53 & 54 & 38 & 43 & 33 & 45 & 17 \\
\hline Geology 1 & $\mathrm{P}$ & $\mathrm{P}$ & $\mathrm{P}$ & $\mathrm{P} / \mathrm{SH}$ & $\mathrm{P} / \mathrm{SH} / \mathrm{Q}$ & $\mathrm{SH} / \mathrm{Q}$ & $\mathrm{SH} / \mathrm{Q}$ & $\mathrm{Q}$ \\
\hline Topographic position ${ }^{2}$ & $\mathrm{~F} / \mathrm{M}$ & $\mathrm{F} / \mathrm{M}$ & $\mathrm{F} / \mathrm{M}$ & $\mathrm{F} / \mathrm{M}$ & $\mathrm{P} / \mathrm{F}$ & $\mathrm{P} / \mathrm{F}$ & $\mathrm{P} / \mathrm{F}$ & $\mathrm{P}$ \\
\hline Slope $\left({ }^{\circ}\right)$ & $1-3$ & $3-5$ & $1-5$ & $1-5$ & $1-3$ & $1-3$ & $1-3$ & $1-3$ \\
\hline Aspect & $\mathrm{E}$ & NW & SE & $\mathrm{S}$ & NS & $\mathrm{N}$ & $\mathrm{N}$ & NESW \\
\hline Predominant soil form ${ }^{3}$ & Gs & $\mathrm{Sn} / \mathrm{Mw}$ & $\mathrm{Va} / \mathrm{Gs}$ & $\mathrm{Sd} / \mathrm{Gs}$ & $\mathrm{Va}$ & Bo & Sn & - \\
\hline Rock cover $(\%)$ & $15-50$ & $10-15$ & $10-20$ & $10-20$ & $05-10$ & $05-10$ & $05-15$ & $05-10$ \\
\hline Mean rock size (mm) & $250-500$ & $100-400$ & $300-500$ & $100-400$ & $200-400$ & $300-400$ & $250-400$ & $50-100$ \\
\hline
\end{tabular}

${ }^{1} \mathrm{P}=$ Pyroxenite $\mathrm{SH}=$ Serpentinized harzburgite; $\mathrm{Q}=$ Alluvium

${ }^{2} \mathrm{M}=$ midslope; $\mathrm{F}=$ footslope; $\mathrm{P}=$ plain

${ }^{3} \mathrm{Bo}=$ Bonheim $; \mathrm{Gs}=$ Glenrosa $; \mathrm{Mw}=$ Milkwood $; \mathrm{Sd}=$ Shortlands $; \mathrm{Sn}=$ Steendal $; \mathrm{Va}=$ Valsrivier 
Table 3

Sekhukhuneland Centre endemic/near-endemic and Red Data List plant taxa recorded for the Potlake Nature Reserve and surrounding areas

\begin{tabular}{|c|c|c|c|c|c|c|c|c|c|}
\hline \multirow[t]{2}{*}{ Taxon } & \multicolumn{4}{|l|}{ Family } & \multicolumn{5}{|c|}{ Syntaxa } \\
\hline & & 1 & 2.1 & 2.2 & 2.3 & 2.4 & 2.5 & 3 & 4 \\
\hline Aloe castanea & LILI & . & . & . & . & . & . & . & \#+ \\
\hline Aloe burgersfortensis & LILI & . & . & $\$+$ & . & . & . & . & . \\
\hline Boscia foetida subsp. minima & CAPP & $\mathrm{Rr}$ & $\operatorname{Rr}$ & . & $\mathrm{Rr}$ & . & $\mathrm{R}+$ & $\mathrm{R}+$ & . \\
\hline Euphorbia sp. nov. (A pers. comm.) & EUPH & . & $\$ \mathrm{r}$ & . & . & . & . & . & . \\
\hline Gossypium herbaceum & MALV & . & . & . & . & $\mathrm{N}+$ & . & . & . \\
\hline Grewia vernicosa & TILI & . & . & . & . & . & . & . & $\# \mathrm{r}$ \\
\hline Hermbstaedtia rogersii & AMAR & . & . & . & . & $\$+$ & $\$ r$ & . & . \\
\hline Heurnia stapelioides & ASCL & . & $\#+$ & 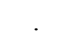 & . & . & . & . & . \\
\hline Hibiscus barnardii & MALV & $\mathrm{R} \$$ & $\mathrm{R} \$$ & $\mathrm{R} \$$ & . & . & . & . & . \\
\hline Leucas capensis [form] (WS 13007) & LAMI & . & $\$ \mathrm{r}$ & $\$ \mathrm{r}$ & $\$+$ & $\$ 1$ & $\$+$ & $\$+$ & $\$+$ \\
\hline Pegolettia senegalensis & ASTE & . & . & . & . & . & $\mathrm{Nr}$ & $\mathrm{N}+$ & . \\
\hline Petalidium oblongifolium & ACAN & $\# 1$ & . & . & . & . & . & . & . \\
\hline Phyllanthus sp. nov. (S 470) & EUPH & $\$ r$ & . & . & . & $\$ \mathrm{r}$ & $\$ r$ & . & . \\
\hline Plinthus rehmannii & AIZO & $\mathrm{V} \#+$ & $\mathrm{V \# +}$ & $\mathrm{V} \# \mathrm{r}$ & $\mathrm{V \# r}$ & $\mathrm{V} \#+$ & $\mathrm{V \# +}$ & . & . \\
\hline Polygala sp. nov. (S 449) & POLY & $\$+$ & . & . & . & $\$ r$ & . & . & . \\
\hline Rhus engleri & ANAC & 1 & & $\#+$ & $\# \mathrm{r}$ & $\# \mathrm{r}$ & $\# 1$ & . & $\# \mathrm{r}$ \\
\hline SCPE Endemics & & 3 & 3 & 3 & 1 & 4 & 3 & 1 & 1 \\
\hline SCPE Near-endemics & & 3 & 3 & 2 & 2 & 2 & 1 & 1 & 2 \\
\hline Red Data List & & 3 & 3 & 2 & 2 & 2 & 3 & 2 & 0 \\
\hline Restricted to syntaxon & & 1 & 2 & 1 & 0 & 1 & 0 & 0 & 2 \\
\hline Restricted to association & & & & & & & & & \\
\hline Total for syntaxon & & 7 & 6 & 5 & 4 & 7 & 6 & 4 & 3 \\
\hline Restricted to association & & & & & & & & 3 & \\
\hline
\end{tabular}

ENDEMISM: $\$=$ endemic, \# = near-endemic; Red DAtA List: $\mathrm{R}=$ Rare, $\mathrm{V}=$ Vulnerable, $\mathrm{N}=$ Not threatened in the northern provinces of South Africa, but in other areas of southern Africa; ABUNDANCE IN COMMUNITIES: 1 = abundant, $+=$ frequent, $\mathrm{r}=$ rare,.$=$ absent; Collectors: $\mathrm{A}=$ Archer, $\mathrm{S}=$ Siebert, $\mathrm{W}=$ Van Wyk; Bold blocks represent community/syntaxon specific taxa.

A vegetation key is presented to facilitate plant community identification (Table 4). The definitions are broad indications of typical groups and should be seen as a guideline. A diagnostic characteristic of the vegetation or habitat is given, followed by the diagnostic and most conspicuous species of a group. The first species is restricted to the specific group only, and the second is dominant in the group, but also occurs in other groups. Where one species is given, no species was restricted to the group only.

\section{Description}

Acacia tortilis-Eragrostis barbinodis Northern Dry Mixed Bushveld of the SCPE is predominantly restricted to the plains and lower slopes of undulating hills. Surface rocks are common and abundant in many of the communities, with soil clay percentages varying from $15 \%$ to $35 \%$. According to the Edwards (1983) classification, the structure of the vegetation is mainly closed tree savanna (undisturbed vegetation), shrubland thick- 
Table 4

Vegetation key to the syntaxa of Potlake Nature Reserve and surrounding areas in the Sekhukhuneland Centre

\begin{tabular}{|c|c|c|}
\hline \multicolumn{2}{|c|}{ Leads/description } & \multirow{2}{*}{$\begin{array}{l}\text { Go to/syntaxon } \\
\text { 1. Panico colorati-Crotonetum menyhartii }\end{array}$} \\
\hline $1 \mathrm{a}$ & $\begin{array}{l}\text { Glenrosa soils only } \\
\quad \text { (Panicum coloratum \& Croton menyhartii) }\end{array}$ & \\
\hline $1 b$ & $\begin{array}{l}\text { Various soil forms } \\
\text { (Acacia grandicornuta \& Panicum maximum) }\end{array}$ & ... 2 \\
\hline $2 \mathrm{a}$ & $\begin{array}{l}\text { Mean rock size }<100 \mathrm{~mm} \\
\quad(\text { Agave americana \& Seddera suffruticosa) }\end{array}$ & 4. Urochloo panicoidis-Agavetum americanae \\
\hline $2 b$ & $\begin{array}{l}\text { Mean rock size }>100 \mathrm{~mm} \\
\quad \text { (Albizia anthelmintica \& Acacia tortilis) }\end{array}$ & $\ldots 3$ \\
\hline $3 a$ & $\begin{array}{l}\text { Steendal soils only } \\
\text { (Salvadora australis \& Tragus berteronianus) }\end{array}$ & $\begin{array}{l}\text { 3. Enneapogono cenchroidis-Salvadoretum } \\
\text { australis }\end{array}$ \\
\hline $3 b$ & $\begin{array}{l}\text { Various soils } \\
\text { (Schmidtia pappophoroides \& Eragrostis barbinodis) }\end{array}$ & $\ldots 4$ \\
\hline $4 a$ & $\begin{array}{l}\text { Pyroxenite only } \\
\text { (Acacia luederitzii \& Tribulus terrestris) }\end{array}$ & $\ldots 5$ \\
\hline $4 b$ & $\begin{array}{l}\text { Pyroxenite and/or harzburgite } \\
\text { (Monechma divaricatum) }\end{array}$ & $\ldots 6$ \\
\hline $5 \mathrm{a}$ & $\begin{array}{l}\text { Mainly northern aspects } \\
\text { (Grewia bicolor \& Lantana rugosa) }\end{array}$ & $\begin{array}{l}2.1 \text { Schmidtio pappophoroidis-Acacietum tortilis } \\
\text { grewetosum bicoloris }\end{array}$ \\
\hline $5 b$ & $\begin{array}{l}\text { Mainly southern aspects } \\
\text { (Rhigozum obovatum \& Balanites maughamii) }\end{array}$ & $\begin{array}{l}\text { 2.2 Schmidtio pappophoroidis-Acacietum tortilis } \\
\text { rhigozetosum obovati }\end{array}$ \\
\hline $6 \mathrm{a}$ & $\begin{array}{l}\text { Footslopes/midslopes } \\
\text { (Diospyros lycioides \& Acacia mellifera) }\end{array}$ & $\begin{array}{l}2.3 \text { Schmidtio pappophoroidis-Acacietum tortilis } \\
\text { diospyretosum lycioidis }\end{array}$ \\
\hline $6 \mathrm{~b}$ & Footslopes/plains (Cadaba termitaria) & $\ldots 7$ \\
\hline $7 \mathrm{a}$ & Valsrivier soils (Acacia nilotica \& Kleinia longiflora) & $\begin{array}{l}2.4 \text { Schmidtio pappophoroidis-Acacietum tortil } \\
\text { is acacietosum niloticae }\end{array}$ \\
\hline $7 \mathrm{~b}$ & $\begin{array}{l}\text { Bonheim soils } \\
\text { (Indigofera rhytidocarpa \& Boscia foetida) }\end{array}$ & $\begin{array}{l}\text { 2.5 Schmidtio pappophoroidis-Acacietum tortilis } \\
\text { indigoferetosum rhytidocarpae }\end{array}$ \\
\hline
\end{tabular}

et (bush encroachment) and open tree savanna (man made grassland).

\section{Urochloo mosambicencis-Acacion tortilis}

all. nova hoc loco

Nomenclatural type: Schmidtio pappophoroidis-Acacietum tortilis (holotypus), association 2 described in this paper.
This alliance is classified under the Panico maximi-Acacietea tortilis (Winterbach et al. 2000). It is related to the Colophospermum mopane-Euclea divinorum Tree Savanna (Van Rooyen et al. 1981) and the Urochloo mosambicensis-Eucleion divinorum (Siebert et al. 2002c).

Habitat. Vegetation representing this alliance could be interpreted as a semi-arid vegeta- 
tion unit driven by rural livelihood systems (this includes overgrazing by goats, irregularly planted fields and intensive wood harvesting), a highly erodable soil profile (weakly structured upper horizons that wash away during heavy rains), and periodic droughts. These habitats occur on gentle footslopes $\left(1-5^{\circ}\right)$ on all aspects (Table 2 ) of the Potlake Nature Reserve and surrounding areas in Sekhukhuneland. The dominant soil forms are the Steendal and Valsrivier forms. Average rock size varies from $100 \mathrm{~mm}$ to $400 \mathrm{~mm}$ and covers $10-50 \%$ of the soil surface (Table 2).

Vegetation structure. The structure represents a transition from pristine savanna to man made grassland to degraded systems with bush encroachment. The alliance is characterised by species group U (Table 1). The forb Seddera suffruticosa, grasses Eragrostis barbinodis and Urochloa mosambicensis, and tree Acacia tortilis are the most abundant diagnostic species of this syntaxon. Acacias are the most distinctive, dominant and largest group of trees for this vegetation type and are generally associated with typical Mixed Bushveld landscapes (Acocks 1988). Other prominent herbaceous species include the forbs Felicia clavipilosa and Kleinia longiflora, and grasses Aristida congesta, Enneapogon cenchroides, Panicum maximum and Tragus berteronianus. Prominent woody taxa of the alliance are Acacia grandicornuta, Albizia anthelmintica, Ehretia rigida and Rhus engleri.

Floristic diversity. It is speculated that much of the vegetation distribution in the semi-arid savanna of the Potlake area can be attributed to the vegetation dynamics and historic evolution of the region, which is influenced by the surrounding flora, continual disturbance by over grazing/harvesting and aridity. Plant species migrations from especially the Pietersburg Plateau (Bredenkamp \& Van Vuuren 1977) and disjunct local occurrences with areas even further north (Van Rooyen et al. 1981), had a considerable influence on the local patterns and species composition of plant communities. Loreau \& Mouquet (1999) demonstrated that local diversity, community patterns and ecosystem processes, are strongly influenced by plant migration. This is further supported by the presence of species typically from higher rainfall areas in the Lowveld, and includes Balanites maughamii, Combretum imberbe, Diospyros mespiliformis, Philenoptera violacea and Ptaeroxylon obliquum. These taxa were recorded in the vicinity of the banks of the Olifants River in Sekhukhuneland.

\section{Panico colorati-Crotonetum menyhartii ass. nova hoc loco}

Nomenclatural type: Relevé 383 (holotypus), Table 1

This association is related to the Loudetio simplicis-Eucleetum linearis and the Enteropogono macrostachyos-Sclerocaryetum birreae (Siebert et al. 2002b).

Habitat. This association occurs on the lower midslopes and footslopes of hills. The habitat is predominantly restricted to eastern aspects that are gently sloped and slightly eroded (Table 2). Loam soils are predominant, mostly the Glenrosa form, with a black coloured ortic A-horizon over a lithocutanic B-horizon. The surface rock cover percentage is high and the mean rock diameter is between $250 \mathrm{~mm}$ and $500 \mathrm{~mm}$ (Table 2).

Vegetation structure. The association represents short, open to closed shrubland of which the diagnostic species are presented in species group A (Table 1). Diagnostic small trees/shrubs of the association are Maerua cafra and Mundulea sericea. Diagnostic forbs include Blepharis pruinosa, Cleome angustifolia, Helichrysum cerastioides, Petalidium oblongifolium and Polygala sp. nov. (Van Wyk \& Siebert 13311). Diagnostic grasses of this association are typical for gravel soils and include Eustachys paspaloides, Fingerhuthia africana and Panicum coloratum. Prominent woody species of the tree cover of $10 \%$ are Acacia mellifera, Balanites maughamii, Croton menyhartii and Rhus engleri. Forb cover is sparse and of the lowest recorded for the study area. Conspicuous grasses of the association 
include Enneapogon scoparius and Eragrostis barbinodis, which contribute substantially towards the grass cover of $14 \%$.

Floristic diversity. This is the most pristine plant community of the Urochloo mosambicencis-Acacion tortilis. Floristically the association shows an affinity with Association 2 in species groups $\mathrm{F}, \mathrm{H}$ and $\mathrm{M}$ (Table 1). The average number of plant species encountered per sample plot is 25 , with the total number for this association being 59 (six relevés) (Table 2). The SCPE near-endemic Petalidium oblongifolium is restricted to this association. A further three endemics, two near-endemics and three Red Data List taxa were recorded for this association (Table 3).

\section{Schmidtio pappophoroidis-Acacietum tortilis ass. nova hoc loco}

Nomenclatural type: Relevé 348 (holotypus), Table 1

This association is related to the Colophospermum mopane-Acacia tortilis-Urochloa mosambicensis Tree Savanna of Van Rooyen et al. (1981) and the Enneapogono cenchroides-Acacietum leiorachis (Siebert et al. 2002c).

Habitat. The association is typical of plains, footslopes and lower midslopes of ultramafic hills. It is managed for grazing purposes in and adjacent to the Potlake Nature Reserve. It is situated on relatively sloped areas $\left(1-5^{\circ}\right)$ with a surface rock cover of 5-15\% (Table 2). Mean rock diameter is approximately 100-500 mm (Table 2).

Vegetation structure. Vegetation is short, sparse to open shrubland that is characterised by the diagnostic taxa presented in species group B (Table 1). The association is typified by a high diversity of herbaceous taxa. Corchorus asplenifolius, Corbichonia decumbens, Limeum viscosum, Melhania rehmannii, Ptycholobium contortum, Solanum coccineum and S. panduriforme are the diagnostic forbs that contribute significantly towards the forb cover of $16 \%$. Diagnostic grasses typical of gravel and/or lime-rich soils are common, namely Schmidtia pappophoroides and Tricholaena monachme. Grass cover is $15 \%$, with the most abundant grasses including Eragrostis barbinodis, Panicum maximum and Tragus berteronianus. Prominent woody species, typical of the association and contributing substantially to the tree cover of $14 \%$ (the highest for the Urochloo mosambicencis-Acacion tortilis), include the small trees Acacia mellifera, Balanites maughamii, Commiphora pyracanthoides and Euclea undulata. Acacia grandicornuta, A. tortilis, Dichrostachys cinerea, Ehretia rigi$d a$ and Rhus engleri are the dominant small trees of the association.

Floristic diversity. The association shows strong floristic affinities with the other associations of the study area in especially species groups $\mathrm{M}, \mathrm{R}$ and $\mathrm{T}$ (Table 1). The average number of plant species encountered per sample plot is 40 , with the total number of species for this association being 164 (34 relevés). Of the four taxa restricted to this association, three are SCPE endemics, namely Aloe burgersfortensis, Euphorbia sp. nov. (Archer pers.comm.) and Hermbstaedtia rogersii, one is a SCPE near-endemic, Huernia stapelioides, and one a Red List taxon, Gossypium herbaceum (Table 3). The highest number of endemics (7), near-endemics (4) and Red List taxa (4) occur in this association, which is also the community with the highest numbers of taxa (13) with conservation value.

\subsection{Schmidtio pappophoroidis-Acaci- etum tortilis grewetosum bicoloris subass. nova hoc loco}

Nomenclatural type: Relevé 354 (holotypus), Table 1

This sub-association represents short thicket on black loam soils underlain by gypsumrich lower horizons. The dominant soil forms are melanic, namely the Steendal form (soft carbonate B-horizon) interspersed by the Milkwood form (A-horizon underlain with hard rock). The community occurs on northern aspects of moderate footslopes and lower midslopes of hills (Table 2). Rock cover is 
sparse. In Table 1, species group C contains the diagnostic species, which is dominated by the diagnostic woody taxa Cadaba aphylla and Grewia bicolor. Diagnostic forbs are Hybanthus enneaspermus, Indigofera tristoides, Limeum pterocarpum, and Tephrosia burchellii, and succulents are Huernia stapelioides, Opuntia ficus-indica (naturalised alien tree) and Talinum arnotii. With the highest tree cover for the study area (28\%), prominent taxa of the sub-association include Acacia grandicornuta, A. mellifera, Albizia anthelmintica, Commiphora pyracanthoides, Croton menyhartii and Ptaeroxylon obliquum. Forb cover is average and includes frequently occurring taxa such as Becium filamentosum, Hibiscus praeteritus, Lantana rugosa, Melhania rehmannii and Seddera suffruticosa. Grass cover is low (9\%) and is dominated by Aristida congesta, Eragrostis barbinodis, Panicum maximum, Schmidtia pappophoroides and Tragus berteronianus. Floristically the sub-association is noteworthy in that, together with subassociation 2.2, it shares a unique link of small forb diversity with association 3 (species group Q; Table 1). This plant community is floristically the richest of the Urochloo mosambicencis-Acacion tortilis, with the highest number of plant species encountered per sample plot (50) and the highest total number recorded per community, namely 110 (five relevés) (Table 2). One SCPE near-endemic, Huernia stapelioides, and one SCPE endemic, Euphorbia sp. nov., are restricted to this sub-association (Table 3).

\subsection{Schmidtio pappophoroidis-Acaci- etum tortilis rhigozetosum obovati subass. nova hoc loco}

Nomenclatural type: Relevé 368 (holotypus), Table 1

This sub-association comprises tall, closed shrubland on footslopes and midslopes. It occurs on relatively deep loam soils of the Valsrivier form (ortic A-horizon over a pedocutanic B-horizon), which is interspersed with shallow soils of the Glenrosa form (ortic A-horizon over a lithocutanic B-horizon). It prefers south-easterly aspects of hills which are characterised by gentle slopes and a rocky surface (Table 2). Species group D (Table 1) includes Rhigozum obovatum, the only diagnostic woody species, and the diagnostic forbs Aneilema hockii, Barleria prionitis, Commelina livingstonii, Melhania virescens, Mollugo nudicaulis and Polygala hottentotta. Other diagnostic species include the succulents Portulaca quatrifida and Stapelia gettliffei. Grasses are common (12\% cover) and Aristida congesta, Eragrostis barbinodis, Panicum maximum and Tragus berteronianus dominate this layer. Frequently occurring forbs are Felicia clavipilosa, Melhania rehmannii, Phyllanthus maderaspatensis and Seddera suffruticosa. Conspicuous trees/shrubs that contribute significantly to the relatively high tree cover of $27 \%$ include Acacia luderitzii, A. tortilis, Croton menyhartii and Ptaeroxylon obliquum. Floristically the sub-association shows the same relationships as sub-association 2.1 (Table 1). A Sekhukhuneland Centre endemic, Aloe burgersfortensis, is restricted to this community within the study area (Table 3), but can also be found in the Mountain Bushveld of the Maandagshoek, Burgersfort, Steelpoort and Dwarsrivier areas.

\subsection{Schmidtio pappophoroidis-Acaci- etum tortilis diospyretosum lycioidis subass. nova hoc loco}

Nomenclatural type: Relevé 360 (holotypus), Table 1

The short, sparse and open tree savanna of this sub-association occurs on footslopes and lower midslopes with red loam soils. Soils are predominantly of the Shortlands form (ortic A-horizon with a red-structured Bhorizon), interspersed with soils of the Glenrosa form. It lies on gently sloped, southern aspects of undulating, ultramafic hills (Table 2). Rock surface cover and size are relatively high (Table 2). Diagnostic species are listed in species group G (Table 1). Diospyros lycioides is the only diagnostic woody species and Eragrostis trichophora 
(along the footpaths) the only diagnostic grass. However, the syntaxon is rich in diagnostic forbs, including Coccinia rehmannii, Dipcadi viride, Melhania acuminata, Phyllanthus incurvus and Pollichia campestris. Dominant grasses such as Aristida congesta, Cenchrus ciliaris, Eragrostis barbinodis, Schmidtia pappophoroides, Tragus berteronianus and Urochloa mosambicensis contribute to a high grass cover of $17 \%$. Forb cover is also relatively high (19\%) and includes the prominent species Blepharis integrifolia, Monechma divaricatum, Pechuel-Loeschea leubnitzia, Phyllanthus maderaspatensis and Seddera suffruticosa. Tree cover is the lowest for the study area (2\%) and includes conspicuous small trees, namely Acacia tortilis, A. mellifera and Ehretia rigida. Species groups $\mathrm{H}$ and $\mathrm{K}$ show the major floristic relationship between this vegetation unit and the other sub-associations of association 2 (Table 1). No taxa with conservation value are restricted to the sub-association, but four taxa of conservation value were recorded (Table 3 ).

\subsection{Schmidtio pappophoroidis-Acaci- etum tortilis acacietosum niloticae subass. nova hoc loco}

Nomenclatural type: Relevé 348 (holotypus), Table 1

A short, closed to open secondary savanna is characteristic of this widespread sub-association. It occurs on heavily grazed, deep, loam/clay soils (500-1000 mm) of the Valsrivier form (ortic A-horizon). It prefers gently sloped footslopes and plains, and can be found on either northern or southern aspects of ultramafic hills (Table 2). The geology is heterogeneous and rock size is relatively large, but rock cover is sparse (Table 2). Diagnostic species are listed in species group I (Table 1) and include the trees Acacia nilotica and Ziziphus mucronata. Diagnostic forbs are plentiful and include Gossypium herbaceum, Hibiscus palmatus, Kohautia cynanchica, Lycium cinereum, Polygala uncinata, Seddera capensis and Tragia rupestris. Eragrostis rigidior is the only diagnostic grass and is characteristic of bare patches in the overgrazed veld. Although disturbed, the grass cover is dense and the highest for the study area (19\%), including unpalatable grasses such as Aristida adscensionis, A. congesta, Enneapogon cenchroides, Eragrostis barbinodis and Tragus berteronianus, and palatable grasses such as Panicum maximum and Urochloa mosambicensis. The sub-association is dominated by encroaching Acacia tortilis trees. Other conspicuous trees include Albizia anthelmintica, Cadaba termitaria, Dichrostachys cinerea and Ehretia rigida. Forbs are abundant $(16 \%)$ and this growth form is dominated by a rich diversity (Corchorus asplenifolius, Gisekia africana, Hermannia odorata, Hibiscus praeterius, Indigastrum costatum, Lantana rugosa, Leucas capensis, Melhania rehmannii, Monechma divaricatum, Phyllanthus maderaspatensis and Solanum panduriforme), which contributes substantially to its recognition as one of the communities with the highest total number of species, namely 110 (11 relevés) (Table 1). Gossypium herbaceum subsp. africanum, a Red Data List taxon described as Insufficiently Known (K) for Swaziland, is the only species restricted to the sub-association (Table 3).

\subsection{Schmidtio pappophoroidis-Acaci- etum tortilis indigoferetosum rhytido- carpae subass. nova hoc loco}

Nomenclatural type: Relevé 370 (holotypus), Table 1

This sub-association of short, open, disturbed savanna in zones of previously cultivated land is common on soils characterised by melanic loams of the Bonheim form (pedocutanic B-horizon). This syntaxon occurs on the plains and on lower footslopes of warmer northern aspects (Table 2). Mean rock size is large, but rock cover is sparse (Table 2). Species group L contains the diagnostic species for this sub-association (Table 1) and includes two grasses, Eragrostis biflora in the shade and the alien Dactyloctenium aegyptium where water collects. No diagnostic woody species were 
recorded, but diagnostic forbs are frequent, and include Indigofera circinnata, I. rhytidocarpa, Ipomoea sinensis, Leucas sexdentata, Limeum sulcatum, Peliostomum leucorrhiza and Trianthema salsoloides. Certain alien species are diagnostic for this sub-association, namely Acalypha segetalis, Amaranthus thunbergii and Schkuhria pinnata. Corallocarpus bainesii, Dipcadi gracillimum, Kohautia aspera and Phyllanthus burchellii are rare indigenous species that were also recorded. Dominant grasses of the sub-association, which contribute substantially to the relatively high grass cover of $18 \%$, include Aristida congesta, Chloris virgata, Eragrostis barbinodis, Sporobolus ioclados, Tragus berteronianus and Urochloa mosambicensis. Prominent forbs are Becium filamentosum, Corchorus asplenifolius, Felicia clavipilosa, Gisekia africana, Hermannia modesta, Phyllanthus maderaspatensis and Seddera suffruticosa. Acacia tortilis dominates the sparse tree cover (3\%), and A. grandicornuta and Dichrostachys cinerea encroaches to a lesser degree. The sub-association is the last of the strong floristic relationship between associations 1 and 2 in species group M (Table 1). A sole relationship, possibly indicating an ecotone, is shared with association 3 in species group $\mathrm{O}$ (Table 1). The plant species diversity per community is high (Table 2) and includes taxa of conservation value (Table 3).

\section{Enneapogono cenchroidis-Salvadoretum australis ass. nova hoc loco}

Nomenclatural type: Relevé 356 (holotypus), Table 1

Habitat. This association occurs on predominantly warm, but locally moister, northerly aspects of ultramafic hills. Mean rock size is high and varies between $250 \mathrm{~mm}$ and $400 \mathrm{~mm}$ in diameter, and covers $5-15 \%$ of the soil surface (Table 2). It is characterised by gentle footslopes and undulating plains (Table 2). The dominant soil form is brackish alluvium of the Steendal form (Table 2).
Vegetation structure. Species group N (Table 1) contains the diagnostic species for this short, closed or open tree savanna in the semi-arid savanna of the SCPE. It is characterised by diagnostic tree species such as Acacia robusta, Cordia monoica, Maerua edulis and Salvadora australis. Diagnostic grasses are plentiful and include Brachiaria deflexa, Diplachne eleusine, Enneapogon desvauxii, Eragrostis curvula and Setaria verticillata. In these relatively undisturbed vegetation units, Abutilon grandiflorum, Hibiscus micranthus, Justicia odora, Pegolettia senegalensis and the succulent Sansevieria hyacinthoides, are the diagnostic forbs of the association. Prominent, frequently occurring trees with a cover of $10 \%$ include Acacia grandicornuta, Boscia foetida and Cadaba termitaria. Aristida adscensionis, Cenchrus ciliaris, Chloris virgata, Enneapogon cenchroides, E. scoparius, Sporobolus ioclados and Tragus berteronianus dominate the grass cover of $15 \%$. Forbs are abundant and the forb layer is well developed with species such as Barleria senensis, B. virgula, Becium filamentosum, Blepharis integrifolia, Hermannia modesta, Ruellia patula and Tribulus terrestris. The forb cover of $20 \%$ is the highest for the study area.

Floristic diversity. Floristically this association shows strong affinities with most of the other associations of the semi-arid savanna of the SCPE, however not including association 1 (Table 1). A very close floristic relationship with association 2 is visible in species group R (Table 1) On average, a high mean number of 48 species were recorded per sample plot for the association, with a total of 98 different plant species overall (four relevés) (Table 2). No taxa of conservation value are restricted to this association; however, one SCPE endemic, one SCPE near-endemic and two Red Data List taxa were recorded (Table 3). 


\section{Urochloo panicoidis-Agavetum} americanae all. nova hoc loco

Nomenclatural type: Relevé 390 (holotypus), Table 1

Habitat. This association occurs on all aspects along gently sloped undulating plains (Table 2). Soils are divers and may include turf soils such as the Arcadia form (vertic A-horizon), clay soils such as the Steendal form (melanic A-horizon), loam soils such as the Shortlands form (ortic Ahorizon, red-structured B-horizon) or sandy soils such as the Hutton form (ortic A-horizon, red-apedale B-horizon). The soil surface is sparsely $(5-10 \%)$ covered by stones with a small mean size of $50-100 \mathrm{~mm}$ (Table 2).

Vegetation structure. This plant community is described as sparse, open, species-poor savanna on disturbed, compacted soils adjacent to natural footpaths of domestic livestock, around settlements of local people, and along natural migration routes of game in the reserve. Diagnostic species are presented in species group S (Table 1). A sparse herb layer dominates the vegetation unit ( $8 \%$ forb cover), with the dominant diagnostic forbs including Aptosimum lineare, Chamaesyce prostrata (alien species), Dicoma tomentosa, Felicia mossamedensis, Geigeria burkei, Indigofera spicata, Melhania forbesii, Phyllanthus parvulus, Sida dregei and Withania somnifera. Diagnostic grasses are Aristida canescens, Eragrostis racemosa and Urochloa panicoides. The large alien succulent, Agave americana, is the most conspicuous diagnostic species in the association. Large individuals of Schotia brachypetala are scattered in this continually disturbed system and dense clumps of the succulent Euphorbia tirucalli are also common. The woody layer is species-poor and sparse (3\% tree cover) due to long-term wood harvesting, overgrazing and trampling by livestock and game. Aristida congesta and Eragrostis barbinodis are other dominant species of the $6 \%$ grass cover of the association. No other common species of the semi-arid savanna of the study area occur frequently in this association.

Floristic diversity. Floristically the association shows a slight relationship with the other associations in species groups $\mathrm{T}$ and $\mathrm{U}$ (Table 1). However, this association is distinct and is only grouped with the other associations due to its locality in the semi-arid savanna of the SCPE and lack of a better placement as a true anthropogenic plant community. Plant species encountered per sample plot are on average 24 and the total number recorded for this association was 55 (three relevés) (Table 2). Two of the recorded taxa of conservation value are restricted to this association for the study area, namely the SCPE near-endemics Aloe castanea and Grewia vernicosa (Table 3).

Ordination

On a regional scale, the area occupied by the Urochloo mosambicencis-Acacion tortilis of the SCPE is characterised as naturally sparsely vegetated due to low rainfall. It contains many syntaxa that are locally typical for this habitat, occurring nowhere else in the SCPE and possibly even the world. When compared with other habitats of the SCPE, the major environmental factors such as climate and geology are relatively homogeneous for this major vegetation group. However, the ordination indicated possible gradients that are mainly influenced by factors such as rock cover, soil moisture and soil depth. All these gradients correlate closely with each other and have a strong influence on the vegetation structure and species composition of the different plant communities (Table 1).

The ordination scatter diagram displays the distribution of relevés along the first and second axes (Fig. 2). The vegetation units are represented as groups, their distribution on the diagram corresponding with certain physical environmental conditions. The rockiness and soil properties determine a definite vegetation gradient that is depicted by both the first (eigen value $=0.629$ ) and second axis (eigen value $=0.344$ ). Rockiness, soil moisture and soil depth determines 


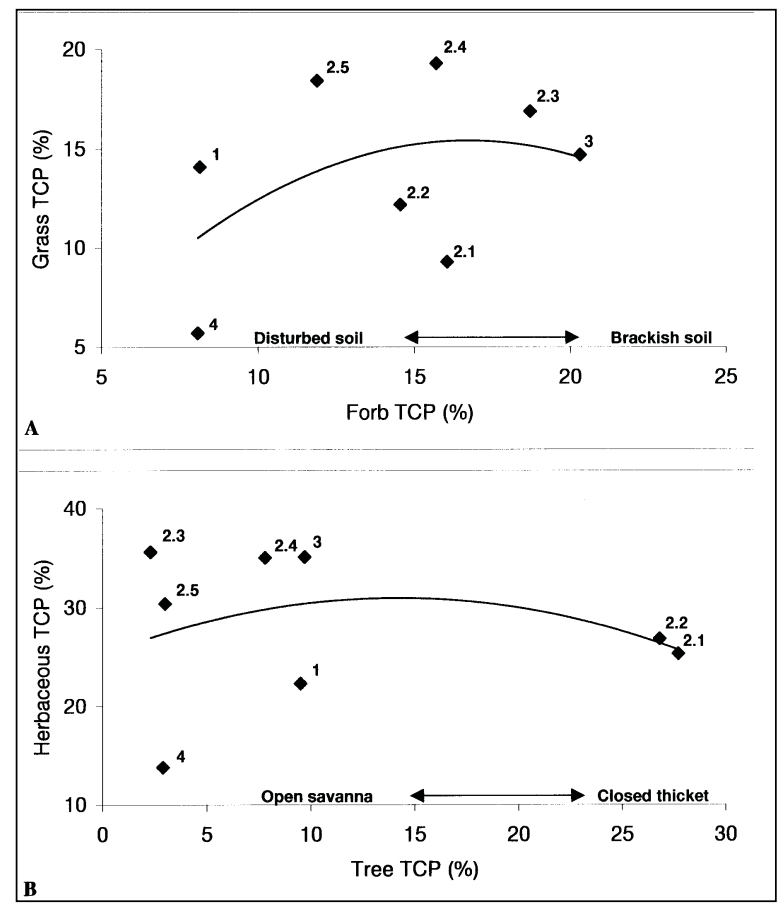

Fig. 3. Total Cover Percentage (TCP) for selected growth forms, as a function of co-existence: (a) grass TCP plotted against forb TCP, and (b) herbaceous (forbs and grasses) TCP plotted against tree TCP.

moisture retention and drainage of any habitat. The gradient on the first axis expresses rock cover as a percentage of the soil surface, with the left of the scatter diagram representing rocky foot slopes and the right depicting the open valley plains. This relates closely to soil moisture, as rock covered soils have reserves of retained moisture in the topsoil which is available for plant uptake. On the second axis, deeper soils located at the bottom of the graph have prolonged water availability, because deep clayey soils retain moisture for a longer period. Steep slopes with shallow soils dry out quickly and are at the top of the diagram. Overall, the scatter diagram expresses a gradient from the shallow, rocky soils in the top, left corner (high available soil moisture, mainly in the wet season) to deep, clay soils in the bottom, right corner (low available soil moisture due to water retention in wet season).

\section{Structure}

To assist future land-use planning, the current relationships between the tree cover and herbaceous layer of the plant communities of the Potlake Nature Reserve and surrounds were investigated and documented. Co-existence graphs can be applied in the future management of the reserve to determine the state of the grass-forb-tree relationship. Briske \& Hendrickson (1998) explain changes in vegetation structure, as a result of over-utilization, as an ecological consequence to minimise the effect of selective grazing/harvesting. Change in vegetation structure will reduce the probability of localised population extinction caused by long-term selective grazing/harvesting. The 
graphs of co-existence can be further applied by establishing control plots to monitor the state of the ecosystem by comparing it to the 20 -year old information provided in this paper.

The trend depicted in Fig. 3a is that of soil quality, with grass cover percentage decreasing as the soil quality decreases. To the left of the diagram the soils have been altered by erosion and compacting, which has made it unsuitable for colonisation by forbs and grasses. Grass cover is a maximum on old fields and heavily grazed areas probably due to a history of fertilisation (sub-associations 2.4 and 2.5). To the right of the diagram, the soil chemistry has been changed by high salt concentrations deposited by non-perennial streams, favouring colonisation by salt tolerant forbs and a decrease in grass cover. The optimum condition for current land-use activities would be one with both the forb and grass TCPs at 15\% each, which means allowing the land to revert back to an optimal system for grazing.

Figure $3 \mathrm{~b}$ illustrates the relationship between tree cover and the understorey herbaceous layer. Tree and herbaceous cover increases linearly, but once the tree cover reaches $15 \%$, there is a noticeable drop in the herbaceous cover due to competition for resources such as light. The communities to the left of the diagram are typically open tree savanna and the communities to the right represent closed thickets. Both the open savanna and the thickets are in some cases a result of anthropogenic and/or natural disturbance. When considering current land-use such as grazing, the optimum condition would be a tree TCP of $15 \%$, which would allow the herbaceous layer to attain a TCP of $30 \%$ and higher. A short, semi-closed savanna would be the ideal structure to protect the soil, and provide enough light for forbs and grasses to co-exist in these semi-arid conditions and, at the same time, provide optimal grazing conditions.

\section{Dynamics}

Classification of the vegetation indicated that intensive long-term grazing and harvest- ing has modified the vegetation structure of this semi-arid savanna type of the SCPE in certain areas, resulting in disturbed plant communities. Altered species composition, decreased biomass and decreased species richness have previously been recorded in the savanna communities of other southern African communal grazing lands (Higgins et al. 1999). Highly degraded ecosystems, especially those in semi-arid regions, do not recover to their original state once the stress loads are lessened (Rapport \& Whitford 1999), for these systems are event-driven (Ellis \& Swift 1988). The semi-arid savanna of the SCPE is probably an event-driven system as it is floristically related to Mopaneveld (Van Rooyen et al. 1981), and should the disturbance be removed, its species composition will return to a type of savanna that will be determined by the environmental factors at that given time (Du Plessis 2001). If the disturbance was drought, the species composition alternates between this event and the one during wetter periods, but will remain stable. However, if the species composition is changed as a result of persistent disturbance, the vegetation seems unable to recover to its so-called stable state. This is the case for the over-utilised areas of semiarid savanna in Sekhukhuneland, with old fields, heavily grazed rangelands, open cast mines and mine dumps covered by a grass layer of annual and alien species infestations (Siebert \& Van Wyk 2001).

Ongoing unsustainable utilisation of the woody canopy of the plant communities in the SCPE semi-arid savanna is detrimental to its future recovery, as it has been shown that the woody canopy of communities in the SCPE has a nurse plant effect on younger seedlings of trees and especially succulents (Thrash 1998). Furthermore, due to continuous intensive grazing in this region, no more protection is given to seedlings against fires and herbivores. Hence, the main factor for vegetation structure, species distribution and depletion during the past 50 years have possibly been anthropogenical. Small-scale disturbances act to increase the range of environmental conditions under which trees and grasses coexist as savanna (Jeltsch et al. 
1998). However, large-scale disturbance, such as the over-harvesting of trees in the SCPE, result in grasslands dominated by annuals or bush encroachment by certain woody species. According to Roth (1999), thorn scrub, a vegetation type of the Dominican Republic which the authors consider as structurally similar to the dominated Acacia tortilis shrublands of this northern part of the SCPE, is a form of secondary climax created through past land-use activities in areas once bearing more diverse dry woodlands. In semi-arid regions where event driven systems prevail, sustained disturbance will alter species composition to such an extent that the original, viable composition may never be regained (Westoby et al. 1989).

\section{Conservation}

An analysis of the size structure in southern African communal lands suggested that land used for grazing have a reduced capacity for regeneration that consequently predicts future species losses (Higgins et al. 1999). Large areas of the study area have already reached this stage and there are now certain vegetation units or areas that need special attention and should be considered for rehabilitation purposes. Throughout the SCPE the remaining wild populations of plants and animals are under intense pressure from the rapid developing mining industry and fast growing human population in the region (Joubert \& Dreyer 2000; Knoll 2002; Siebert et al. 2002d). Certain plant endemics and rare taxa of this semi-arid region of the SCPE are restricted to specific communities. Areas containing these communities require immediate attention as conservation priorities. Furthermore, like in other centres of plant diversity of the world (Stohlgren 1999), alien plant invasions pose a significant challenge to the unique species composition of habitats and distinctive plant communities in this part of the SCPE. To further protect these unique species assemblages, attention needs to be given to the protection of important species with conservation value, such as local endemic, near-endemic and threatened taxa (Table 2). The creation of nature reserves and/or resource reserves is one solution to this problem. If its size could be increased, the Potlake Nature Reserve could be the solution to protect a large part of this unique semi-arid savanna. However, financial constraints, frequent droughts, illegal plant harvesting and unsustainable former land-use have left its scars in this reserve and its surrounds.

\section{Conclusions}

The TwINSPAN classification and its subsequent refinement by Braun-Blanquet procedures resulted in the delineation of eight plant communities. These communities can be related to certain environmental factors, the gradients of which are proposed in the DECORANA scatter diagram. Moisture availability plays a major role in the survival of the plant species and therefore soil depth and rock cover are major determinants of the species composition of the communities. Different events related to land-use history and current management practices, as well as natural factors such as soil structure, determine the current structure and distribution of these savanna plant communities.

Description and classification of the different vegetation units of Potlake Nature Reserve and its surrounds makes a significant contribution towards the understanding of the semi-arid regions of the SCPE. However, further more detailed ecological studies need to be done on old fields and degraded systems of different ages to derive hypothetical succession pathways for future grazing management in especially the Potlake Nature Reserve and its surrounding grazing areas. Proper and sound assessments of the region's vegetation (including aspects such as species richness and threats) to determine its suitability for conservation are a prerequisite before suggestions concerning sustainable development and conservation can be made (Bedward et al. 1992). The information supplied in this paper can be meaningfully applied to develop management and conservation plans for this species rich, but threatened, area. 


\section{Acknowledgements}

Our appreciation to Ms Martie Dednam, H.G.W.J. Schweikerdt Herbarium (PRU), University of Pretoria, for processing the plant specimens and to Dr Elizabeth Retief, National Herbarium (PRE), Pretoria, for assistance with plant identifications. A special thanks to staff at the Department of Botany, University of Pretoria, namely Ms Franci du Plessis for assistance with numerical analysis, Prof. George Bredenkamp for guidance with the descriptions and Prof. Noel van Rooyen for supervising the fieldwork of Ms Maryna Matthee in Potlake Nature Reserve during 1978. The National Research Foundation, University of Pretoria, Andrew Mellon Foundation and Department of Environmental Affairs and Tourism, financially supported the research.

\section{References}

AcocKs, J.P.H. 1988. Veld types of South Africa. Memoirs of the Botanical Survey of South Africa 57: 1-146.

Bedward, M., R.L. Pressey \& D.A. Keith. 1992. A new approach for selecting fully representative reserve networks: addressing efficiency, reserve design and land suitability with an iterative analysis. Biological Conservation 62: 115-125.

BREDENKAMP, G.J. \& D.R.J. van VuUREN. 1977. The plant communities below Turfloop Dam, Lebowa. Pietersburg: University of the North. (Series A17)

BreebaArt, L. \& M. Deutschländer. 1997. The vegetation types and management units of Goedverwacht farm in the mixed bushveld of the Northern Province, South Africa. Koedoe 40: 19-33.

BRISKe, D.D. \& J.R. HENDRICKSON. 1998. Does selective defoliation mediate competitive interactions in a semiarid savanna? A demographic evaluation. Journal of Vegetation Science 9: 611-622.

Buckle, C. 1996. Weather and Climate in Africa. Harlow: Addison Wesley Longman.

CoDD, L.E.W. 1949. The application of ecology to agricultural problems in South Africa. Statement and Communication of the African Regional Scientific Conference, pp. 115-119.

Du Plessis, F. 2001. A phytosociological synthesis of Mopaneveld. M.Sc. dissertation, University of Pretoria, Pretoria.

EDWARDS, D. 1983. A broad-scale structural classification of vegetation for practical purposes. Bothalia 14: 705-712.

ElLIS, J.E. \& D.M. SwIFT. 1988. Stability of African pastoral systems: Alternate paradigms and implications for development. Journal of Range Management 41: 450-459.

ERASMus, J.F. 1985. Rainfall deciles for the Transvaal Region. Pretoria: Soil and Irrigation Research Institute. (Report GB/A/87/18)

HeNneKens, S. 1996a. TuRBOVEG: Software package for input, processing, and presentation of phytosociological data. User's guide. University of Lancaster: IBN-DLO.

Hennekens, S. 1996b. Megatab: A visual editor for phytosociological tables. Version 1.0. User's guide. Ulft: Giesen \& Geurts.

HigGins, S.I., C.M. SHACKLETON \& E.R. Robinson. 1999. Changes in woody community structure and composition under contrasting landuse systems in a semi-arid savanna, South Africa. Journal of Biogeography 26: 619-627.

HILl, M.O. 1979a. TWINSPAN - a FORTRAN program for arranging multivariate data in an ordered two way table by classification of individuals and attributes. New York: Cornell University, Ithaca.

HiLl, M.O. 1979b. DECORANA - a FORTRAN program for detrended correspondence analysis and reciprocal averaging. New York: Cornell University, Ithaca.

Hilton-TAYlor, C. 1996. Red Data List of southern African plants. Pretoria: National Botanical Institute. (Strelitzia 4)

Jeltsch, F., S.J. Milton, W.R.J. Dean, N. Van RoOYen \& K.A. Moloney. 1998. Modelling the impact of small-scale heterogeneities on treegrass coexistence in semi-arid savannas. Journal of Ecology 86: 780-793.

JOUBERT, H. \& A. DREYER. 2000. Rocky road for rare endemics: granite mining threatens a rich Mpumalanga environment. African Wildlife 54: 18-19.

KNOLL, C. 2002. Operation Wildflower: Plant rescue at andalusite mine. Urban Green File 7: 19-21.

Land Type Survey Staff. 1987. Land types of the maps 2526 Rustenburg, 2528 Pretoria. Pretoria: Department of Agriculture and Water Supply. (Memoirs on the Agricultural Natural Resources of South Africa No. 8)

LOREAU, M. \& N. MOUQUET. 1999. Immigration and the maintenance of local species diversity. The American Naturalist 154: 427-440.

Matthews, W.S. 1991. Phytosociology of the Northeastern Mountain Sourveld. M.Sc. dissertation, University of Pretoria, Pretoria.

Mucina, L., G.J. Bredenkamp, D.B. Hoare \& D.J. MCDONALD. 2000. A national vegetation database for South Africa. South African Journal of Science 96: 497-498.

Mueller-Dombois, D. \& H. Ellenberg. 1974. Aims and methods of vegetation ecology. New York: Wiley. 
Retief, E. \& P.P.J. Herman. 1997. Plants of the northern Provinces of South Africa: keys and diagnostic characters. Pretoria: National Botanical Institute. (Strelitzia 6)

RotH, L.C. 1999. Anthropogenic change in subtropical dry forest during a century of settlement in Jaiqui Picado, Santiago Province, Dominican Republic. Journal of Biogeography 26: 739-759.

SIEBERT, S.J. 1998. Ultramafic substrates and floristic patterns in Sekhukhuneland, South Africa. M.Sc. dissertation, University of Pretoria, Pretoria.

Siebert, S.J. \& A.E. VAN WyK. 2001. Sekhukhuneland: floristic wealth versus platinum and chromium riches. Veld \& Flora 87: 168-173.

SieBert, S.J., A.E. VAN WyK \& G.J. BREDENKAMP. 2001. Endemism in the flora of ultramafic areas of Sekhukhuneland, South Africa. South African Journal of Science 97: 529-532.

Siebert, S.J., A.E. VAN WyK \& G.J. BREdenKamp. 2002a. The physical environment and major vegetation types of Sekhukhuneland, South Africa. South African Journal of Botany 68: 127142.

Siebert, S.J., A.E. VAN WyK \& G.J. BRedenKamp. 2002b. Vegetation ecology of Sekhukhuneland, South Africa: Combretum hereroense-Grewia vernicosa Open Mountain Bushveld. South African Journal of Botany 68: 475-496.

Siebert, S.J., A.E. VAN WYK \& G.J. BREDENKAMP. 2002c. Vegetation ecology of Sekhukhuneland, South Africa: Kirkia wilmsii-Terminalia prunioides Closed Mountain Bushveld. South African Journal of Botany 68: 497-517.

Siebert, S.J., J.E. Victor, A.E. VAN WyK \& G.J. BREDENKAMP. 2002d. An assessment of threatened plants and conservation in Sekhukhuneland. PlantLife 26: 7-18.

South African Weather Bureau. 1998. Unpublished report. Department of Environmental Affairs and Tourism, Pretoria.

Stohlgren, T.J., D. Binkley \& G.W. Chong. 1999. Exotic plant species invade hot spots of native plant diversity. Ecological Monographs 69: 2546.

THRASH, I. 1998. Association of three succulent plant species with woody canopy in the mixed bushveld, South Africa. Koedoe 41(1): 95-101.

Van Rooyen, N., G.K. Theron \& N. GrobbelaAr. 1981. A floristic description and structural analysis of the plant communities of the Punda Milia-Pafuri-Wambiya area in the Kruger National Park. Journal of South African Botany 47: 585-626.

VAN WyK, A.E. \& G.F. SMITH. 2001. Regions of floristic endemism in southern Africa: a review with emphasis on succulents. Pretoria: Umdaus Press.

Victor, J.E. 2002. South Africa. Pp. 93-120. In: Golding, J.S. (ed). Southern African Plant Red Data Lists. Pretoria: SABOnEt. (SABONET Report Series No. 14)

Visser, D.J.L., F.J. Coertze \& F. Walraven. 1989. Explanation of the 1:1000000 geological map, fourth edition, 1984: the geology of the Republics of South Africa, Transkei, Bophuthatswana, Venda and Ciskei and the Kingdoms of Lesotho and Swaziland. Pretoria: The Government Printer.

Weber, H.E., J. Moravec \& J-P. Theurillat. 2000. International Code of Phytosociological Nomenclature. Journal of Vegetation Science 11: 739768.

Westoby, M., B. Walker \& I. Noy-Meir. 1989. Opportunistic management for rangelands at equilibrium. Journal of Range Management 42: 266-274.

WHITTAKER, R.H. 1977. Evolution of species diversity in land communities. Evolutionary Biology 10: 1-67.

Winterbach, R., G.J. Bredenkamp, M.S. DeutschLÄNDER \& L. MuCINA. 2000. Preliminary syntaxonomic scheme of vegetation classes for the Central Bushveld of South Africa. Pp. 123-127. In: White, P.S., L. Mucina, J.S. LePS \& E. VAN Der MaArel (eds.). Proceedings IAVS Symposium. Uppsala: Opulus Press. 